(c) American Dairy Science Association, 2006.

\title{
Short Communication: A Polymorphism in ABCG2 in Bos indicus and Bos taurus Cattle Breeds
}

\author{
M. Ron, ${ }^{*}$ M. Cohen-Zinder, ${ }^{\star}$ C. Peter, $†$ J. I. Weller, ${ }^{*}$ and G. Erhardt† \\ ${ }^{*}$ Department of Ruminants and Genetics, Agricultural Research Organization, P.O.B. 6, Bet-Dagan 50-250, Israel \\ †Department of Animal Breeding and Genetics, Justus-Liebig-University Giessen, Ludwigstrasse 21b, 35390 Giessen, Germany
}

\begin{abstract}
A single nucleotide change $(\mathrm{A} / \mathrm{C})$ in exon 14 is capable of encoding a substitution of tyrosine-581 to serine (Y581S) in the ABCG2 (ATP binding cassette, subfamily $\mathrm{G}$, member 2 ) gene and affects milk production traits. The $A B C G 2^{A}$ allele decreases milk yield and increases protein and fat concentration. The allele frequencies were determined in 32 Bos taurus and 3 Bos indicus breeds; $A B C G 2^{A}$ was predominant in all populations. This allele approached fixation in 23 out of 35 breeds, including all 3 Bos indicus breeds. The $A B C G 2^{C}$ allele was found in the Belgian Blue (beef), Belgian Blue Mix, British Friesian, Bohemian Red, East Anatolian Red, German Angus, German Black Pied, German Brown, German Simmental, Israeli Holstein, Menorquina, and US Holstein breeds. Thus, the genetic gain expected from selection for $A B C G 2^{A}$ may be limited. The detection of $A B C G 2^{C}$ only in Bos taurus breeds may indicate that $A B C G 2^{A}$ is the ancestral allele, and that the Y581S substitution occurred after the separation of the Bos indicus and Bos taurus lineages.
\end{abstract}

Key words: ATP binding cassette G2 gene, Bos taurus chromosome 6 , single nucleotide polymorphism

Many studies have found segregating QTL for milk production traits on Bos taurus chromosome (BTA) 6 in different dairy cattle populations (reviewed by Khatkar et al., 2004; http://bovineqtl.tamu.edu/index.html). Cohen-Zinder et al. (2005) found a single nucleotide polymorphism $(\mathrm{A} / \mathrm{C})$ in exon 14 capable of encoding a substitution of tyrosine-581 to serine (Y581S) in the ABCG2 transporter gene. They provided evidence that Y581S is the causative polymorphism for the QTL on BTA6 affecting milk yield and composition. The protein encoded by $A B C G 2$, a member of the ATP binding cassette (ABC) superfamily, transports various xenobiotics and cytostatic drugs

Received March 21, 2006.

Accepted July 5, 2006.

${ }^{1}$ Corresponding author: Georg.Erhardt@agrar.uni-giessen.de across the plasma membrane (Litman et al., 2000). The $A B C G 2$ gene was not expressed in virgin mice, but was greatly induced during late pregnancy and especially during lactation (Jonker et al., 2005). The effects of the $A B C G 2^{A}$ allele, which decreases milk yield and increases protein and fat concentration, are economically favorable for most selection indexes used in dairy cattle breeding programs (Miglior et al., 2005). Thus, as proposed by several studies reviewed by Weller (2001), rates of genetic gain can be increased by direct selection on this allele. However, if the favorable allele is already at high frequency, then the possible gain by direct selection is limited (Cohen-Zinder et al., 2005).

The first identified causative gene for a QTL in dairy cattle, DGAT1, is located on BTA14 and chiefly affects milk fat percentage (Grisart et al., 2002). Kaupe et al. (2004) estimated allele frequencies for DGAT1 in 38 cattle breeds from 5 continents, and found that frequencies of the 2 alleles ranged from zero to fixation. The aim of this study was to determine the allele frequencies for $A B C G 2$ using the same DNA resource, with the addition of the Israeli and US Holstein breeds, to predict the genetic gain obtainable by fixation of the favorable allele.

The analysis included 341 Israeli and 9 US Holstein bulls genotyped previously (Cohen-Zinder et al., 2005), and 724 individuals from 33 additional Bos taurus and Bos indicus breeds (Kaupe et al., 2004) that were genotyped for this single nucleotide polymorphism by DNA MassArray technology (Sequenom Inc., San Diego, CA) following Cohen-Zinder et al. (2005). Nine DNA samples determined to be heterozygous by MassArray were sequenced. All traces showed double peaks (A/ C), validating the MassArray genotypes. Allele frequencies and the corresponding standard errors (SE) were calculated using SPSS V 12.0 (SPSS, Inc., Chicago, IL).

Allele frequencies for the $A B C G 2$ gene in the 35 breeds are presented in Table 1 . The $A B C G 2^{A}$ allele was predominant in all populations. The $A B C G 2^{C}$ allele was not detected in any of the 3 Bos indicus breeds analyzed, but was detected in 12 Bos taurus breeds: Belgian Blue (beef), Belgian Blue Mix, British 
Table 1. Number of animals genotyped per breed and allele frequencies of the $A B C G 2$ gene with standard errors (SE)

\begin{tabular}{|c|c|c|c|c|}
\hline \multirow[b]{2}{*}{ Breed $^{1}$} & \multirow{2}{*}{$\begin{array}{l}\text { Animals } \\
\text { genotyped, } \\
\mathrm{n}\end{array}$} & \multicolumn{2}{|c|}{ Allele frequencies } & \multirow[b]{2}{*}{$\mathrm{SE}$} \\
\hline & & $A B C G 2^{A}$ & $A B C G 2^{C}$ & \\
\hline Aberdeen Angus & 25 & 1.00 & 0.00 & \\
\hline Anatolian Black & 31 & 1.00 & 0.00 & \\
\hline Angler & 30 & 1.00 & 0.00 & \\
\hline Asturian Mountain & 43 & 1.00 & 0.00 & \\
\hline Ayrshire & 32 & 1.00 & 0.00 & \\
\hline Banyo Gudali & 67 & 1.00 & 0.00 & \\
\hline Belgian Blue (beef) & 28 & 0.95 & 0.05 & \pm 0.041 \\
\hline Belgian Blue mix & 8 & 0.94 & 0.06 & \pm 0.084 \\
\hline Bohemian Red & 35 & 0.99 & 0.01 & \pm 0.017 \\
\hline British Friesian & 37 & 0.93 & 0.07 & \pm 0.042 \\
\hline Casta Navarra & 19 & 1.00 & 0.00 & \\
\hline Charolais & 10 & 1.00 & 0.00 & \\
\hline Chianina & 36 & 1.00 & 0.00 & \\
\hline East Anatolian Red & 28 & 0.88 & 0.12 & \pm 0.061 \\
\hline German Yellow & 6 & 1.00 & 0.00 & \\
\hline German Angus & 18 & 0.92 & 0.08 & \pm 0.064 \\
\hline German Black Pied & 22 & 0.93 & 0.07 & \pm 0.054 \\
\hline German Brown & 22 & 0.95 & 0.05 & \pm 0.046 \\
\hline German Brown Swiss & 21 & 1.00 & 0.00 & \\
\hline German Holstein & 27 & 1.00 & 0.00 & \\
\hline German Simmental & 22 & 0.86 & 0.14 & \pm 0.074 \\
\hline Hereford & 39 & 1.00 & 0.00 & \\
\hline Israeli Holstein ${ }^{2}$ & 341 & 0.80 & 0.20 & \pm 0.022 \\
\hline Menorquina & 15 & 0.97 & 0.03 & \pm 0.044 \\
\hline N'Dama & 7 & 1.00 & 0.00 & \\
\hline Nellore & 8 & 1.00 & 0.00 & \\
\hline Pezzata Rossa & 18 & 1.00 & 0.00 & \\
\hline Pinzgauer & 9 & 1.00 & 0.00 & \\
\hline Polish Red & 11 & 1.00 & 0.00 & \\
\hline Santa Gertrudis ${ }^{3}$ & 11 & 1.00 & 0.00 & \\
\hline South Anatolian Red & 17 & 1.00 & 0.00 & \\
\hline Toro de Lydia & 13 & 1.00 & 0.00 & \\
\hline Turkish Gray Steppe & 9 & 1.00 & 0.00 & \\
\hline US Holstein ${ }^{2}$ & 9 & 0.95 & 0.05 & \pm 0.073 \\
\hline White Fulani & 9 & 1.00 & 0.00 & \\
\hline
\end{tabular}

${ }^{1}$ Bos indicus breeds are in italics; other breeds are Bos taurus.

${ }^{2}$ Cohen-Zinder et al., 2005.

${ }^{3}$ Santa Gertrudis was included in Bos taurus breeds because it contains 5/8 Shorthorn and 3/8 Brahman.

Friesian, Bohemian Red, East Anatolian Red, German Angus, German Black Pied, German Brown, German Simmental, Israeli Holstein, Menorquina, and US Holstein. In these breeds, allele frequencies of $A B C G 2^{A}$ ranged from $80 \%$ in Israeli Holstein to $99 \%$ in Bohemian Red. Observed heterozygote frequencies were very close to the expected values, by Hardy-Weinberg equilibrium, for all breeds in which both alleles were segregating. The $A B C G 2^{C}$ allele was detected in most of the cattle breeds that segregated for the QTL; including the US, German, and Israeli dairy breeds (Khatkar et al., 2004). In view of the high frequency of the $A B C G 2^{A}$ allele across all breeds, the genetic gain expected from selection for this allele may be limited. From 1990 through 2002 frequency of the $A B C G 2^{A}$ allele in the Israeli Holstein population increased from 0.62 to 0.77 ; and mean breeding values in the cow population increased by $327 \mathrm{~kg}$ of milk, $34.2 \mathrm{~kg}$ of fat, $30.2 \mathrm{~kg}$ of protein, $0.21 \%$ fat, and $0.19 \%$ protein. These changes correspond to the adoption of a breeding index in 1991 based chiefly on protein with a negative weight for milk yield. Assuming additive gene action and that the allelic substitution effect is $0.2 \%$ protein (CohenZinder et al., 2005), the gain obtained by raising the frequency of the $A B C G 2^{A}$ allele by 0.1 should be $0.04 \%$ protein. Thus, the increase of 0.15 in the frequency of the $A B C G 2^{A}$ allele should have resulted in a gain of $0.06 \%$ protein, which accounts for only one-third of the realized gain in protein concentration obtained during these $12 \mathrm{yr}$. The remainder of this gain must be due to other genes.

The detection of $A B C G 2^{C}$ only in Bos taurus breeds may indicate that $A B C G 2^{A}$ is the ancestral allele, and that the Y581S substitution occurred after the separation of the Bos indicus and Bos taurus lineages over 200,000 yr ago (Loftus et al., 1999). This is also the scenario proposed for the $D G A T 1^{K}$ allele (Kaupe et al. 2004).

\section{ACKNOWLEDGMENTS}

We thank Sion, Israel; E. M. Ibeagha-Awemu and O. C. Jann, Germany; C. Özbeyaz and N. Eker, Turkey; J. L. Williams, Scotland; P. Ajmone-Marsan, Italy; P. Zaragoza, Spain; J. Citek, Czech Republic; R. Zieminski, Poland; K. Moazami-Goudarzi, France; H. Lenstra, the Netherlands; L. Panicke, Germany; and the German AI stations for the contribution of samples. Genotyping was performed at the Genome Knowledge Center at the Weizmann Institute of Science (Rehovot, Israel).

\section{REFERENCES}

Cohen-Zinder, M., E. Seroussi, D. M. Larkin, J. J. Loor, A. Evertsvan der Wind, J. H. Lee, J. K. Drackley, M. R. Band, A. G. Hernandez, M. Shani, H. A. Lewin, J. I. Weller, and M. Ron. 2005. Identification of a missense mutation in the bovine $A B C G 2$ gene with a major effect on the QTL on chromosome 6 affecting milk yield and composition in Holstein cattle. Genome Res. 15:936-944.

Grisart, B., W. Coppieters, F. Farnir, L. Karim, C. Ford, P. Berzi, N. Cambisano, M. Mni, S. Reid, P. Simon, R. Spelman, M. Georges, and R. Snell. 2002. Positional candidate cloning of a QTL in dairy cattle: Identification of a missense mutation in the bovine DGAT1 gene with major effect on milk yield and composition. Genome Res. 12:222-231.

Jonker, J. W., G. Merino, S. Musters, A. E. van Herwaarden, E. Bolscher, E. Wagenaar, E. Mesman, T. C. Dale, and A. H. Schinkel. 2005. The breast cancer resistance protein BCRP (ABCG2) concentrates drugs and carcinogenic xenotoxins into milk. Nat. Med. 11:127-129.

Kaupe, B., A. Winter, R. Fries, and G. Erhardt. 2004. DGAT1 polymorphism in Bos indicus and Bos taurus cattle breeds. J. Dairy Res. 7:182-187.

Khatkar, M. S., P. C. Thomson, I. Tammen, and H. W. Raadsma. 2004. Quantitative trait loci mapping in dairy cattle: Review and meta-analysis. Genet. Sel. Evol. 36:163-190. 
Litman, T., M. Brangi, E. Hudson, P. Fetch, A. Abati, D. D. Ross, K. Miyake, J. H. Resau, and S. E. Bates. 2000. The multidrugresistant phenotype associated with overexpression of the new ABC half-transporter, MXR (ABCG2). J. Cell Sci. 113:20112021.

Loftus, R. T., O. Ertugrul, A. H. Harba, M. A. El-Barody, D. E. MacHugh, S. D. Park, and D. G. Bradley. 1999. A microsatellite survey of cattle from a centre of origin: The Near East. Mol. Ecol. 8:2015-2022.

Miglior, F., B. L. Muir, and B. J. Van Doormaal. 2005. Selection indices in Holstein cattle of various countries. J. Dairy Sci. $88: 1255-1263$.

Weller, J. I. 2001. Quantitative Trait Loci Analysis in Animals. CABI Publishing, London, UK. 